\title{
Sistem Pendukung Keputusan Pemilihan Jenis Lampu untuk Pencahayaan Ruangan Menggunakan Metode AHP
}

\author{
Habrifio Chandradirgant Ponamon, Yaulie D. Y. Rindengan, Muhamad D. Putro \\ Teknik Informatika Universitas Sam Ratulangi Manado, Indonesia. \\ habrifio@gmail.com,rindengan@unsrat.ac.id,dwisnantoputro@unsrat.ac.id
}

\begin{abstract}
Abstrak - Masalah yang disebabkan oleh karena kurangnya atau berlebihan pencahayaan dalam ruangan mengakibatkan aktivitas menjadi terganggu misalnya ketika salah memilih lampu. Metode Analytical Hierarchy Process (AHP) dapat digunakan untuk pemilihan jenis lampu untuk pencahayaan ruangan, dimana kriteria dapat ditentukan oleh pembeli atau melihat spesifikasi jenis atau merek lampu. Kriteria yang digunakan yaitu Ketahanan, Hemat Energi, Harga, Jenis Lampu dan Warna sedangkan produk alternatif yang digunakan yaitu Kawachi, Hori, Panasonic dan Philips. Hasil yang akan dicapai adalah Sistem Pendukung Keputusan (SPK) pemilihan jenis lampu berbasis web untuk menentukan merek lampu yang akan akan digunakan sesuai keinginan konsumen dengan menggunakan metode Waterfall sebagai metodologi perancangan sistem.
\end{abstract}

Kata Kunci : AHP, Lampu, Pencahayaan, SPK, Waterfall

\section{PENDAHULUAN}

Perkembangan zaman yang semakin maju seperti sekarang ini membuat kebutuhan masyarakat semakin meningkat pula. Terlebih lagi dengan adanya faktor pecahayaan ruangan. Pencahayaan merupakan salah satu faktor penting dalam perancangan ruang untuk menunjang kenyamanan pengguna. Ruang dengan sistem pencahayaan yang baik dapat mendukung aktivitas yang dilakukan di dalamnya.

Sistem pencahayaan yang baik harus memenuhi tiga kriteria utama kualitas, kuantitas, dan aturan pencahayaan. Kurangnya dukungan pencahayaan dalam suatu ruang mengakibatkan aktivitas dalam ruangan tersebut manjadi terganggu misalnya ketika pencahayaan terlalu berlebihan akan berakibat mengganggu penglihatan. Dengan demikian intensitas cahaya perlu diatur untuk menghasilkan kesesuaian kebutuhan penglihatan di dalam ruang berdasarkan jenis aktivitas.

Sebagai contoh dengan adanya lampu segala kegiatan yang terjadi dalam ruangan dapat dilakukan dengan baik dan juga cepat. Sekarang ini lampu merupakan suatu kebutuhan dasar bagi masyarakat lebih khusus yang beraktivitas di dalam ruangan. Namun untuk memilih lampu yang tepat dan sesuai kebutuhan dan anggaran bukanlah hal yang mudah karena perbandingan harga setiap merek lampu sangant bersaing serta setia merek lampu memiliki spesifikasi berbeda-beda. Setiap orang dalam menentukan pilihan sering mendapati suatu keadaan dimana orang harus memilih satu dari beberapa pilihan yang ada.
Sistem pendukung keputusan merupakan subuah alternaif solusi atau alternatif tindakan dari sejumlah alternatif dan tindakan guna menyelesaikan suatu masalah, sehingga masalah tersebut dapat diselesaikan secara efektif dan efisien.

Oleh karena itu penelitian ini akan membahas sistem pendukung keputusan yang diharapkan dapat membantu dalam pemilihan lampu sesuai dengan keinginan. Metode yang di pakai adalah metode Analytical Hierarchy Process (AHP) karena metode ini adalah sebuah hirarki fungsional dengan input utamanya persepsi manusia dalam hal ini orang yang mengerti permasalahan jenis lampu.

\section{LANDASAN TEORI}

\subsection{Sistem Pendukung Keputusan (SPK)}

Sistem Pendukung Keputusan merupakan sistem inormasi interaktif yang menyediakan informasi, pemodelan dan manipulasi data. Sistem itu digunakan untuk membantu pengambilan keputusan dalam situasi yang semistruktural dan situasi yang tidak terstruktur dimana tak seorang pun tau secara pasti bagaimana keputusan seharusnya dibuat (Riyani, Awang Harsa Kiradalaksana dan Ahmad Rofiq Hakim, 2010).

Sistem pengambilan keputusan biasanya dibangun untuk mendukung solusi atau suatu masalah atau untuk mengevaluasi suatu peluang. Sistem pengambilan keputusan yang seperti ini disebut aplikasi sistem pengambilan keputusan digunakan dalam mengambil suatu keputusan. Aplikasi menggunakan CBIS (Computer Based Information System) yang fleksibel, interaktif, dan dapat diadaptasi yang dikembangkan untuk mendukung solusi atas manajemen spesifik yang tidak terstruktur. Aplikasi Sistem pengambilan keputusan menggunakan data, memberikan antar muka pengguna yang mudah, dan dapat menggabungkan pikiran pengambilan keputusan. Sistem pengambilan keputusan lebih ditunjukan untuk mendukung manajemen dalam melakukan pekerjaan yang bersifat analitis dalam situasi yang kurang terstruktur dan dengan kriteria yang kurang jelas. [1]

\subsection{Analytical Hierarchy Process (AHP)}

Analytic Hierarchy Process (AHP) adalah sebuah hirarki fungsional dengan input utamanya persepsi manusia. Dengan hirarki, suatu masalah dapat kompleks dan tidak terstruktur di pecahkan kedalam kelompok-kelompoknya. Kemudian kelompok-kelompok tersebut di atur menjadi suatu bentuk hirarki. Suatu tujuan yang bersifat umum dan dapat di 
jabarkan dalam beberapa subtujuan yang lebih terperinci yang akan menjalankan apa yang akan dimaksudkan dalam bentuk pertama. Penjabaran ini dilakukan tersusun hingga akhirnya diperoleh tujuan yang bersifat operasional. Dan pada hirarki terendah inilah dilakukan proses-proses evaluasi atas alternatif-alternatif, yang merupakan ukuran dari pencapaian tujuan utama, dan pada hirarki terendah ini dapat ditetapkan dalam satuan apa kriteria diukur. Dalam penjabaran hirarki tujuan, tidak ada pedoman yang pasti seberapa jauh pengambilan keputusan menjabarkan tujuan menjadi tujuan yang lebih rendah(Kadarsah Suryadi, 1998). [2]

Adapun tahap proses perhitungan Analytic Hierarchy Process (AHP) yaitu sebagai berikut:

1. Menyusun hirarki dari permasalahan

2. Membuat matriks pebandingan berpasangan

3. Menentukan nilai keseluruhan prioritas atau Total Priority Value (TPV) dengan menjumlahkan nilai tiap kolom dan membagi dengan jumlah kolom.

4. Memeriksa konsistensi Consistency Ratio (CR) dengan langkah-langkah sebagai berikut :

a. Menentukan nilai rata-rata ( $\lambda$ maks) dengan rumus :

$$
\lambda \text { maks }=(\lambda \text { maks } \mathrm{K} 1+\ldots+\lambda \text { maks } \mathrm{Kn}) / \mathrm{n} \ldots .(1)
$$

$$
\begin{aligned}
\text { Keterangan }: \lambda \text { maks } & =\text { Nilai Rata-Rata Kriteria } \\
\mathrm{K} & =\text { Kriteria } \\
\mathrm{n} & =\text { Jumlah Kriteria }
\end{aligned}
$$

b. Mencari nilai Consistency Index (CI) dengan rumus :

$$
\mathrm{CI}=(\lambda \operatorname{maks}-\mathrm{n} /(\mathrm{n}-1))
$$

$$
\begin{gathered}
\text { Keterangan : } \mathrm{CI}=\text { Consistency Index } \\
\lambda \text { maks }=\text { Nilai Rata-Rata Kriteria } \\
\mathrm{n} \quad=\text { Jumlah Kriteria }
\end{gathered}
$$

c. Menghitung nilai Consistency Ratio (CR) dengan rumus :

$$
\mathrm{CR}=\mathrm{CI} / \mathrm{RI}
$$

$$
\begin{aligned}
\text { Dimana }: \text { CR } & =\text { Consistency Ratio } \\
\mathrm{CI} & =\text { Consistency Index } \\
\mathrm{RI} & =\text { Random Index }
\end{aligned}
$$

\subsection{Lampu}

Lampu merupakan salah satu komponen penting dalam penerangan, baik di dalam ruangan maupun luar ruangan. Lampu memberikan manfaat yang sangat besar khususnya pada malam hari. Teknologi lampu dalam memberikan pencahayaan saat ini telah banyak membantu aktivitas masyarakat dalam melakukan pekerjaan sehari-hari. Karena peranan lampu sangat penting maka banyak industri-industri penciptakan berbagai produk dan merek lampu dari yang murah sampai mahal. Lampu-lampu yang sering digunakan saat ini adalah lampu neon, lampu pijar dan lampu LED.[3]

\subsection{Pencahayaan}

Pencahayaan diambil dari kata dasar cahaya yang merupakan salah satu bagian jenis gelombang elektromagnetis yang terbang ke angkasa. Gelombang tersebut memiliki panjang dan frekuensi tertentu, yang nilainya dapat dibedakan dari energi cahaya lainnya.

Fungsi pencahayaan adalah sebagai penerang ruang untuk mendukung kegiatan yang berlangsung dalam ruang tersebut. Selain itu, pencahayaan juga dapat memberikan nilai lebih dalam suatu ruang, antara lain, dapat membangun suasana ruang, efek fisik dan psikologis adalah satu kesatuan yang saling mempengaruhi pencahayaan.

Pencahayaan yang terang akan membuat pengguna ruang merasa terbangun dan sangat aktif. Sedangkan pencahayaan yang redup menciptakan rasa rileks bahkan mungkin mengantuk.[3]

\subsection{Ruangan}

Ruangan diambil dari kata ruang yang artinya wujud fisik wilayah dalam dimensi geografis geometris yang merupakan wadah bagi manusia dalam melaksanakan kegiatan kehidupannya dalam suatu kualitas kehidupan yang layak. (D. A. Tisnaadmidjaja, 1997). [3]

\section{6. $P H P$}

Jaka P (2014), PHP (Hypertext Preprocessor) adalah bahasa skrip yang dapat ditanamkan atau disisipkan ke dalam HTML/PHP banyak digunakan untuk membuat situs web dinamis. Tujuan utama penggunaan bahasa ini adalah untuk memungkinkan perancang dan menulis halaman web menjadi dinamis dengan cepat. [4]

\section{7. $M y S Q L$}

Nuh (2012), MySQL adalah salah satu perangkat lunak Database Management System (DBMS) yang sering digunakan pada saat ini, yang didistribusikan secara gratis di bawah lisensi GPL (GNU General Public Licence). Sehingga setiap orang mudah untuk mendapatkan dan bebas menggunakan MySQL. Pengertian MySQL termasuk ke dalam jenis software pada Relational Database Management System (RDBMS) pada sebuah manajemen database sebagai basis data. [5]

\subsection{Metode Waterfall}

Menurut Pressman (2010), Metode Waterfall merupakan salah satu medel dalam perancangan perangkat lunak. Proses dari metode waterfall antara lain Communication, Planning, Modeling, Costruction, dan Deployment.

1. Communication (Komunikasi)

Langkah ini merupakan analisis terhadap kebutuhan software dan tahap untuk mengadakan pengumpulan data dengan melakukan pertemuan dengan customer, maupun mengumpulkan data-data tambahan baik yang ada di jurnal, artikel, maupun dari internet.

2. Planning (Perancangan)

Proses planning merupakan lanjutan dari proses communication (analysis requirment). Tahapan ini akan menghasilkan dokumen user requirment atau bisa dikatakan sebagai data yang berhubungan dengan keinginan user dalam pembuatan software, termasuk rencana yang akan dilakukan.

3. Modeling (Pemodelan) 
Proses modeling ini akan menerjemahkan syarat kebutuhan ke sebuah perancangan software yang diperkirakan sebelum dibuat coding. Proses ini berfokus pada rancangan struktur data, arsitektur software, representasi interface, detail (algoritma) prosedural. Tahapan ini akan menghasilkan dokumen yang disebut software requirment.

4. Construction (Konstruksi)

Construction merupakan proses membuat kode (coding). Coding atau pengkodean merupakan penerjemahan desain dalam bahasa yang bisa dikenali oleh komputer. Programmer akan menerjemahkan transaksi yang diminta oleh user. Tahapan inilah yang merupakan tahapan secara nyata dalam mengerjakan suatu software, artinya penggunaan komputer akan dimaksimalkan dalam tahapan ini. Setelah pengkodean selesai maka akan dilakukan testing terhadap sistem yang telah dibuat tadi. Tujuan dari testing adalah menemukan kesalahan-kesalahan terhadap sistem tersebut untuk kemudian bisa diperbaiki.

5. Deployment (Penyerahan)

Tahapan ini bisa dikatakan final dalam pembuatan sebuah software atau sistem. Setelah melakukan analisis, desain dan pengkodean maka sistem yang sudah jadi akan digunakan oleh user. Kemudian software yang telah dibuat harus evaluasi jika ada kekurangan dan dilakukan pemeliharaan secara berkala.

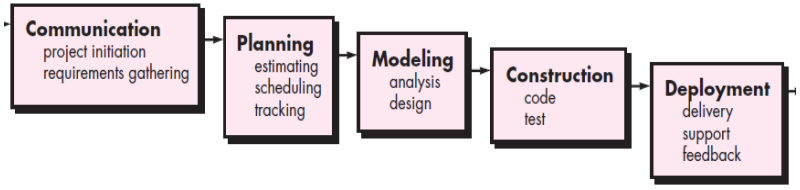

Gambar 2.1 Proses Metode Waterfall (Sumber : Pressman, 2010) [6]

\section{METODOLOGI PENELITIAN}

\subsection{Metode Pengumpulan Data}

Dalam penelitian ini untuk mengumpulkan data adalah wawancara dan studi pustaka.

1. Studi Pustaka adalah usaha yang dilakukan oleh peneliti untuk menghimpun informasi yang relevan dengan topik atau masalah yang akan atau sedang diteliti. Informasi itu dapat diperoleh dari buku-buku ilmiah, laporan penelitian, karangan-karangan ilmiah dan lain-lain.

2. Wawancara adalah metode pengumpulan data yang dilakukan berupa komunikasi secara langsung dengan narasumber untuk mendapatkan informasi yang dibutuhkan dan Studi. Untuk penelitian ini melakukan komunikasi dan wawancara secara langsung dengan pemilik toko mengenai kriteria dan alternatif jenis atau merek lampu yang dibutuhkan konsumen.

\subsection{Metode Pengembangan Sistem}

Dalam penelitian ini untuk metode pengembangan sistem pengambilan keputusan adalah metode Waterfall. Dalam metode pengembangan sistem ini terdapat langkah-langkah yang harus dilakukan yaitu Komunikasi, Perencanaan, Pemodelan, Konstruksi dan Pengujian.

Aktivitas yang dilakukan pada tahap komunikasi yaitu mendapatkan informasi yang dibutuhkan dalam membangun sisem. Aktivitas yang dilakukan pada tahap perencanaan adalah menyusun rencana kerja dalam membangun sistem. Aktivitas yang dilakukan pada tahap pemodelan yaitu menganalisa perancangan proyek. Okleh karena itu sistem yang dibangun berorientasi objek maka sistem menggunakan diagram UML yaitu use case diagram dan use case description. Aktivitas yang dilakukan pada tahap konstruksi adalah melakukan penulisan kode-kode program. Aktivitas yang dilakukan pada tahap pengujian adalah menguji alur bisnis apakah perhitungan AHP yang dilakukan sistem sudah benar atau tidak.

\subsection{Pemodelan sistem}

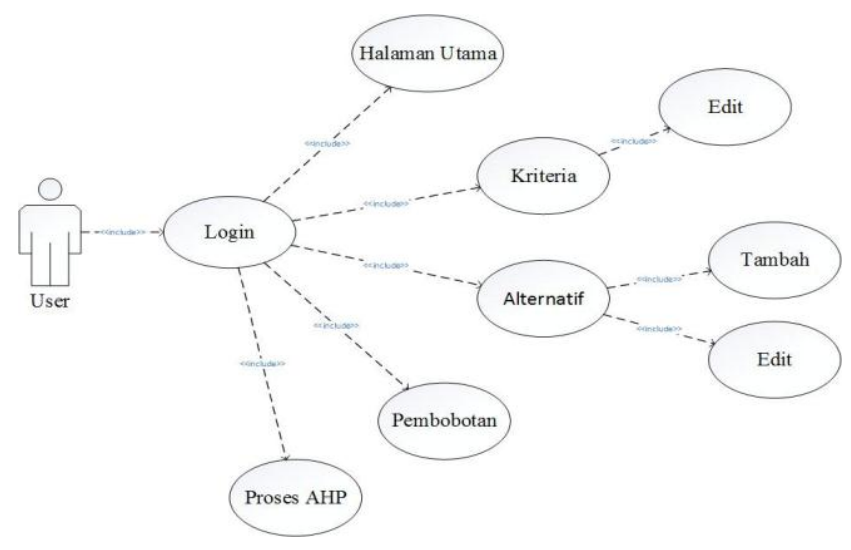

Gambar 3.1 Use Case Dagram

Gambar diatas menunjukan fungsi dan tanggung jawab user untuk mengakses setiap halaman yang ada dalam sistem dengan melihat halaman utama, melakukan penambahan dan pengeditan kriteria dan alternatif serta melakukan pembobotan dan melihat hasil akhir melalui proses AHP.

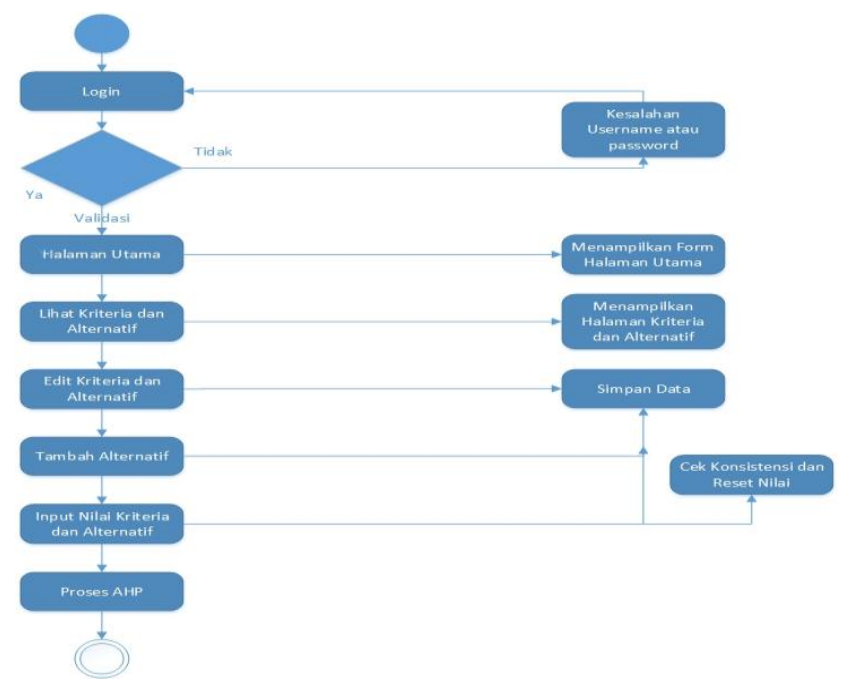

Gambar 3.2 Activity Diagram 
Gambar di atas menunjukan aktivitas-aktivitas yang dilakukan oleh user kemudian sistem akan memproses setiap permintaan yang diminta user.

\section{HASIL DAN PEMBAHASAN}

\subsection{Perhitungan Analytic Hierarchy Process (AHP)}

\subsubsection{Perhitungan AHP untuk Kriteria}

Langkah pertama menentukan matriks perbandingan berpasangan dengan membandingkan setiap elemen, dengan cara membeikan nilai 1-9 adalah skala untuk membandingkan setiap elemen. Contoh nilai perbandingan adalah kriteria Ketahanan dibandingkan dengan kriteria Harga bernilai 5 maksudnyakriteria Ketahanan sangat penting dibandingkan dengan kriteria Harga.

Tabel 4.1 Matriks Pebandingan Berpasangan

\begin{tabular}{|l|c|c|c|c|c|}
\hline \multicolumn{1}{|c|}{ Kriteria } & Ketahanan & $\begin{array}{c}\text { Hemat } \\
\text { Energi }\end{array}$ & Harga & Jenis lampu & Wama \\
\hline Ketahanan & 1 & 3 & 5 & 7 & 7 \\
\hline Hemat energi & 0.333 & 1 & 3 & 5 & 5 \\
\hline Harga & 0.2 & 0.333 & 1 & 3 & 3 \\
\hline Jenis lampu & 0.143 & 0.2 & 0.333 & 1 & 2 \\
\hline Warna & 0.143 & 0.2 & 0.333 & 0.5 & 1 \\
\hline
\end{tabular}

Setelah menentukan matriks berpasangan kemudian menjumlahkan nilai setiap kolom.

Tabel 4.2 Penjumlahan Kolom

\begin{tabular}{|l|l|l|l|l|l|}
\hline \multicolumn{1}{|c|}{ Kriteria } & Ketahanan & $\begin{array}{c}\text { Hemat } \\
\text { Energi }\end{array}$ & Harga & $\begin{array}{c}\text { Jenis } \\
\text { lampu }\end{array}$ & Wama \\
\hline Ketahanan & 1 & 3 & 5 & 7 & 7 \\
\hline Hemat Energi & 0.333 & 1 & 3 & 5 & 5 \\
\hline Harga & 0.2 & 0.333 & 1 & 3 & 3 \\
\hline Jenis lampu & 0.143 & 0.2 & 0.333 & 1 & 2 \\
\hline Warna & 0.143 & 0.2 & 0.333 & 0.5 & 1 \\
\hline Jumlah & 1.819 & 4.733 & 9.666 & 16.5 & 18 \\
\hline
\end{tabular}

Kemudian membagi nilai kolom dengan jumlah kolom untuk memperoleh normalisasi matriks dan menjumlahkan nilai tiap baris kemudian membagi jumlah elemen untuk mendapatkan nilai prioritas (TPV).

Tabel 4.3 Normalisasi Matriks dan Nilai Prioritas (TPV)

\begin{tabular}{|l|l|l|l|l|l|l|}
\hline \multicolumn{1}{|c|}{ Kriteria } & Ketahanan & $\begin{array}{c}\text { Hemat } \\
\text { Energi }\end{array}$ & Harga & $\begin{array}{c}\text { Jenis } \\
\text { lampu }\end{array}$ & Wama & TPV \\
\hline Ketahanan & 0.55 & 0.634 & 0.517 & 0.424 & 0.389 & 0.503 \\
\hline Hemat Energi & 0.183 & 0.211 & 0.310 & 0.303 & 0.278 & 0.257 \\
\hline Harga & 0.11 & 0.070 & 0.103 & 0.182 & 0.167 & 0.126 \\
\hline Jenis lampu & 0.079 & 0.042 & 0.034 & 0.061 & 0.111 & 0.065 \\
\hline Wama & 0.079 & 0.042 & 0.034 & 0.030 & 0.056 & 0.048 \\
\hline
\end{tabular}

Setelah itu memeiksa konsistensi (Consistency Ratio atau $\mathrm{CR}$ ) matriks perbandingan kriteria. Matriks perbandingan dapat dikatakan konsisten jika nilai $\mathrm{CR}<0.1$, tetapi apabila nilai $C R>0.1$ maka pembobotan dibuat kembali.

Langkah pertama mencari nilai Principle Eigen Value ( $\lambda$ $\max$ )

$$
\begin{aligned}
\lambda \max = & (1.819 \times 0.503)+(4.733 \times 0.257)+(9.666 \times \\
& 0.126)+(16.5 \times 0.065)+(18 \times 0.048) \\
= & 0.915+1.216+1.218+1.072+0.864 \\
= & 5.285
\end{aligned}
$$

Kemudian mencari nilai Consistency Index (CI)

$$
\begin{aligned}
\mathrm{CI} & =\lambda \max -\mathrm{n} / \mathrm{n}-1 \\
& =5.285-5 / 5-1 \\
& =0.285 / 4 \\
& =0.071
\end{aligned}
$$

Setelah itu mencari nilai Consistency Ratio (CR)

$$
\begin{aligned}
\mathrm{CR} & =\mathrm{CI} / \mathrm{RI} \\
& =0.071 / 1.12 \\
& =0.064
\end{aligned}
$$

\subsubsection{Perhitungan AHP untuk Alternatif}

Berikut ini merupakan pembobotan untuk alternatif pada kriteria.

1. Alternatif untuk Kriteria Ketahanan

Nilai perbandingan dan penjumlahan kolom pada alternatif untuk kriteria ketahanan.

Tabel 4.4 Matriks Perbandingan Alternatif untuk Kriteria Ketahanan

\begin{tabular}{|l|l|l|l|l|}
\hline Ketahanan & Kawachi & Panasonic & Hori & Philips \\
\hline Kawachi & 1 & 3 & 2 & 0.333 \\
\hline Panasonic & 0.333 & 1 & 0.333 & 0.2 \\
\hline Hori & 0.5 & 3 & 1 & 0.333 \\
\hline Philips & 3 & 5 & 3 & 1 \\
\hline Jumlah & 4.833 & 12 & 6.333 & 1.866 \\
\hline
\end{tabular}

Kemudian menghitung normalisasi matriks dan prioritas vektor (TPV).

Tabel 4.5 Normalisasi matriks dan Prioritas Vektor Alternatif untuk Kriteria Ketahanan

\begin{tabular}{|l|l|l|l|l|l|}
\hline Ketahanan & Kawachi & Panasonic & Hori & Philips & $T P V$ \\
\hline Kawachi & 0.207 & 0.250 & 0.316 & 0.178 & 0.238 \\
\hline Panasonic & 0.069 & 0.083 & 0.052 & 0.107 & 0.078 \\
\hline Hori & 0.103 & 0.250 & 0.158 & 0.178 & 0.172 \\
\hline Philips & 0.621 & 0.417 & 0.474 & 0.536 & 0.512 \\
\hline
\end{tabular}

$$
\begin{aligned}
\Lambda \max = & (4.833 \times 0238)+(12 \times 0.078)+(6.333 \times \\
& 0.172)+(1.866 \times 0.512) \\
= & 1.150+0.936+1.096+0.955 \\
= & 4.137 \\
= & 4.137-4 / 4-1 \\
= & 0.137 / 3 \\
= & 0.046 \\
= & 0.046 / 0.9 \\
= & 0.051
\end{aligned}
$$

Oleh karena $\mathrm{CR}<0.1$ maka pembobotan tersebut konsisten. 
2. Alternatif untuk Kriteria Hemat Energi

Nilai perbandingan dan penjumlahan kolom pada alternatif untuk kriteria hemat energi.

Tabel 4.6 Matriks Perbandingan Alternatif untuk

Kriteria Hemat Energi

\begin{tabular}{|l|l|l|l|l|}
\hline Hemat Energi & Kawachi & Panasonic & Hori & Philips \\
\hline Kawachi & 1 & 3 & 5 & 2 \\
\hline Panasonic & 0.333 & 1 & 3 & 0.333 \\
\hline Hori & 0.2 & 0.333 & 1 & 0.2 \\
\hline Philips & 0.5 & 3 & 5 & 1 \\
\hline Jumlah & 2.033 & 7.333 & 14 & 3.533 \\
\hline
\end{tabular}

Kemudian menghitung normalisasi matriks dan prioritas vektor (TPV).

Tabel 4.7 Normalisasi matriks dan Prioritas Vektor Alternatif untuk Kriteria Hemat Energi

\begin{tabular}{|l|l|l|l|l|l|} 
Harga & Kawachi & Panasonic & Hori & Philips & TPV \\
\hline Kawachi & 0.071 & 0.045 & 0.098 & 0.057 & 0.068 \\
\hline Panasonic & 0.214 & 0.136 & 0.164 & 0.094 & 0.152 \\
\hline Hori & 0.357 & 0.409 & 0.492 & 0.566 & 0.456 \\
\hline Philips & 0.357 & 0.409 & 0.246 & 0.283 & 0.324 \\
\hline
\end{tabular}

$\Lambda \max =(2.033 \times 0.456)+(7.333 \times 0.153)+(14 \times$ $0.068)+(3.533 \times 0.324)$

$$
=0.927+1.121+0.952+1.145
$$$$
=4.145
$$

CI $=4.145-4 / 4-1$

$=0.145 / 3$

$$
=0.048
$$

$\mathrm{CR}=0.048 / 0.9$

$$
=0.053
$$

Oleh karena $\mathrm{CR}<0.1$ maka pembobotan tersebut konsisten.

3. Alternatif untuk Kriteria Harga

Nilai perbandingan dan penjumlahan kolom pada alternatif untuk kriteria harga.

Tabel 4.8 Matriks Perbandingan Alternatif untuk

Kriteria Harga

\begin{tabular}{|l|l|l|l|l|}
\hline Harga & Kawachi & Panasonic & Hori & Philips \\
\hline Kawachi & 1 & 0.333 & 0.2 & 0.2 \\
\hline Panasonic & 3 & 1 & 0.333 & 0.333 \\
\hline Hori & 5 & 3 & 1 & 2 \\
\hline Philips & 5 & 3 & 0.5 & 1 \\
\hline Jumlah & 14 & 7.333 & 2.033 & 3.533 \\
\hline
\end{tabular}

Kemudian menghitung normalisasi matriks dan prioritas vektor (TPV).
Tabel 4.9 Normalisasi matriks dan Prioritas Vektor Alternatif untuk Kriteria Harga

\begin{tabular}{|l|l|l|l|l|l|}
\hline Hemat Energi & Kawachi & Panasonic & Hori & Philips & TPV \\
\hline Kawachi & 0.492 & 0.409 & 0.357 & 0.566 & 0.456 \\
\hline Panasonic & 0.164 & 0.136 & 0.214 & 0.094 & 0.153 \\
\hline Hori & 0.098 & 0.045 & 0.071 & 0.057 & 0.068 \\
\hline Philips & 0.246 & 0.409 & 0.357 & 0.283 & 0.324
\end{tabular}

$$
\begin{aligned}
\Lambda \max = & (14 \times 0.068)+(7.333 \times 0.152)+(2.033 \times \\
& 0.456)+(3.533 \times 0.324) \\
= & 0.952+1.115+0.927+1.145 \\
= & 4.139 \\
= & 4.139-4 / 4-1 \\
= & 0.139 / 3 \\
\mathrm{CI} \quad & 0.046 \\
\mathrm{CR} \quad & 0.046 / 0.9 \\
= & 0.051
\end{aligned}
$$

Oleh karena $\mathrm{CR}<0.1$ maka pembobotan tersebut konsisten.

4. Alternatif untuk Jenis Lampu

Nilai perbandingan dan penjumlahan kolom pada alternatif untuk kriteria jenis lampu.

Tabel 4.10 Matriks Perbandingan Alternatif untuk

Kriteria Jenis Lampu

\begin{tabular}{|l|l|l|l|l|}
\hline Jenis Lampu & Kawachi & Panasonic & Hori & Philips \\
\hline Kawachi & 1 & 0.333 & 2 & 0.333 \\
\hline Panasonic & 3 & 1 & 3 & 2 \\
\hline Hori & 0.5 & 0.333 & 1 & 0.333 \\
\hline Philips & 3 & 0.5 & 3 & 1 \\
\hline Jumlah & 7.5 & 2.166 & 9 & 3.666 \\
\hline
\end{tabular}

Kemudian menghitung normalisasi matriks dan prioritas vektor (TPV).

Tabel 4.11 Normalisasi matriks dan Prioritas

Vektor Alternatif untuk Kriteria Jenis Lampu

\begin{tabular}{|l|l|l|l|l|l|}
\hline Jenis Lampu & Kawachi & Panasonic & Hori & Philips & TPV \\
\hline Kawachi & 0.133 & 0.154 & 0.222 & 0.091 & 0.15 \\
\hline Panasonic & 0.4 & 0.462 & 0.333 & 0.545 & 0.435 \\
\hline Hori & 0.067 & 0.154 & 0.111 & 0.091 & 0.106 \\
\hline Philips & 0.4 & 0.231 & 0.333 & 0.273 & 0.309 \\
\hline
\end{tabular}

$$
\begin{aligned}
\Lambda \max = & (7.5 \times 0.15)+(2.166 \times 0.435)+(9 \times 0.106) \\
& +(3.666 \times 0.309) \\
= & 1.125+0.942+0.954+1.133 \\
= & 4.157 \\
\mathrm{CI} \quad & 4.157-4 / 4-1 \\
= & 0.157 / 3 \\
= & 0.052 \\
\mathrm{CR} \quad & 0.052 / 0.9
\end{aligned}
$$




$$
=0.058
$$

Oleh karena $\mathrm{CR}<0.1$ maka pembobotan tersebut konsisten.

5. Alternatif untuk Warna

Nilai perbandingan dan penjumlahan kolom pada alternatif untuk kriteria warna.

Tabel 4.12 Matriks Perbandingan Alternatif untuk Kriteria Warna

\begin{tabular}{|l|l|l|l|l|} 
Wama & Kawachi & Panasonic & Hori & Philips \\
\hline Kawachi & 1 & 3 & 3 & 3 \\
\hline Panasonic & 0.333 & 1 & 2 & 2 \\
\hline Hori & 0.333 & 0.5 & 1 & 2 \\
\hline Philips & 0.333 & 0.5 & 0.5 & 1 \\
\hline Jumlah & 2 & 5 & 6.5 & 8 \\
\hline
\end{tabular}

Kemudian menghitung normalisasi matriks dan prioritas vektor (TPV).

Tabel 4.13 Normalisasi matriks dan Prioritas Vektor Alternatif untuk Kriteria Warna

\begin{tabular}{|l|l|l|l|l|l|}
\hline Wama & Kawachi & Panasonic & Hori & Philips & TPV \\
\hline Kawachi & 0.5 & 0.6 & 0.461 & 0.375 & 0.480 \\
\hline Panasonic & 0.167 & 0.2 & 0.308 & 0.25 & 0.231 \\
\hline Hori & 0.167 & 0.1 & 0.154 & 0.25 & 0.168 \\
\hline Philips & 0.167 & 0.1 & 0.077 & 0.125 & 0.117 \\
\hline
\end{tabular}

$\Lambda \max =(2 \times 0.484)+(5 \times 0.231)+(6.5 \times 0.168)+(8$ $\mathrm{x} 0.117)$

$$
=0.962+1.115+1.092+0.936
$$

$$
=4.145
$$

CI $=4.145-4 / 4-1$

$$
=0.145 / 3
$$$$
=0.048
$$

$\mathrm{CR}=0.048 / 0.9$

$$
=0.054
$$

Oleh karena $\mathrm{CR}<0.1$ maka pembobotan tersebut konsisten.

\subsubsection{Perangkingan untuk Pemilihan Jenis Lampu}

Berdasarkan hasil prioritas vektor dari setiap kriteria dan alternatif maka hasilnya akan dijumlahkan dan diperoleh total nilai hasil perhitungan yang dijadikan sebagai rangking untuk menentukan jenis lampu yang sesuai.
Tabel 4.14 Hitung Composite Weight

\begin{tabular}{|l|l|l|l|l|l|}
\hline & $\begin{array}{c}\text { Nilai } \\
\text { Priority } \\
\text { Kriteria }\end{array}$ & Kawachi & Panasonic & Hori & Philips \\
\hline Ketahanan & 0.502 & 0.238 & 0.078 & 0.172 & 0.512 \\
\hline Hemat Energi & 0.267 & 0.456 & 0.153 & 0.068 & 0.324 \\
\hline Harga & 0.126 & 0.068 & 0.152 & 0.456 & 0.324 \\
\hline Jenis Lampu & 0.065 & 0.15 & 0.435 & 0.106 & 0.309 \\
\hline Warna & 0.048 & 0.484 & 0.231 & 0.168 & 0.117 \\
\hline
\end{tabular}
$\mathrm{x} 0.068)+(0.065 \mathrm{x} 0.15)+(0.048 \mathrm{x}$ $0.484)$

$=0.119+0.122+0.008+0.01+0.023$

$=0.282$

Panasonic $=(0.503 \times 0.078)+(0.267 \times 0.153)+(0.126$ $\times 0.152)+(0.065 \times 0.435)+(0.048 \times$ $0.231)$

$=0.039+0.041+0.019+0.028+0.011$

$=0.138$

Hori $=(0.503 \times 0.172)+(0.267 \times 0.068)+$ $(0.126 \times 0.456)+(0.065 \times 0.106)+$ $(0.048 \times 0.168)$

$=0.086+0.018+0.057+0.007+0.008$ $=0.176$

Phlips $=(0.503 \times 0.512)+(0.267 \times 0.324)+(0.126$ $\times 0.324)+(0.065 \times 0.309)+(0.048 \times$ $0.117)$

$=0.257+0.086+0.041+0.02+0.006$ $=0.41$

Tabel 4.15 Perangkingan

\begin{tabular}{|l|c|c|}
\hline $\begin{array}{l}\text { Merek } \\
\text { Lampu }\end{array}$ & Hasil & Rangking \\
\hline Philips & 0.41 & 1 \\
\hline Kawachi & 0.282 & 2 \\
\hline Hori & 0.176 & 3 \\
\hline Panasonic & 0.138 & 4 \\
\hline
\end{tabular}

Berdasarkan tabel diatas maka hasil akhir atau kesimpulan dari perhitungan manual didapatkan merek atau produk alternatif terbaik yang mendapatkan rangking 1 adalah Philips.

\subsection{Interface Sistem}

Bagian ini merupakan pembahasan tentang fungsi dan penggunaan setiaphalaman aplikasi yang berbasis web. 


\subsubsection{Halaman Login}

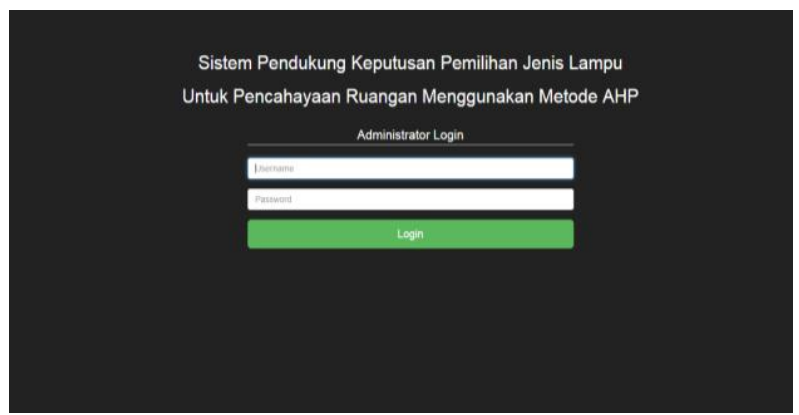

Gambar 4.1 Halaman Login

Gambar diatas adalah halaman untuk menginput username dan password agar masuk pada halaman utama.

\subsubsection{Halaman Utama}

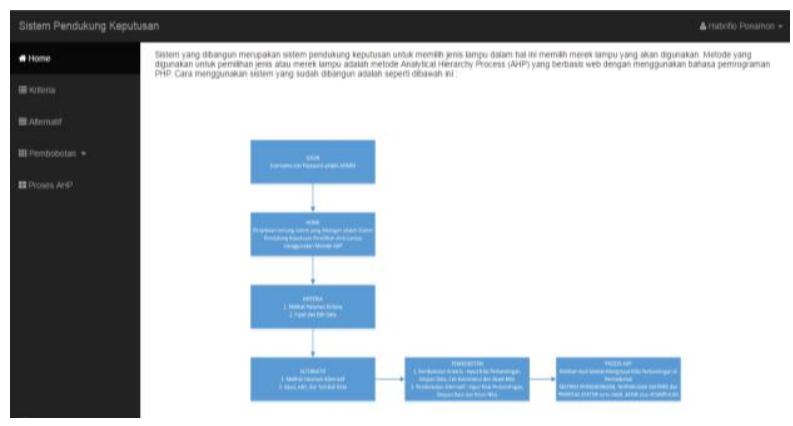

Gambar 4.2 HalamanUtama

Gambar diatas merupakan tampilan halaman utama sistem yang terdiri dari lima menu yaitu home, kriteria, alternatif, pembobotan dan proses AHP.

\subsubsection{Halaman Kriteria}

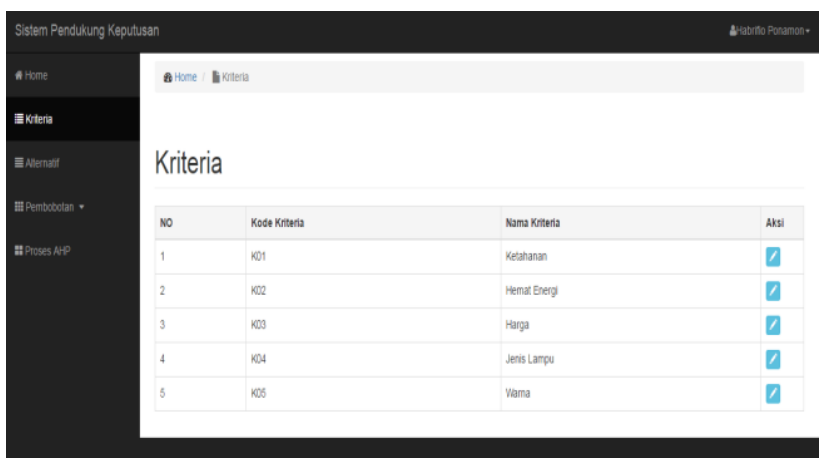

Gambar 4.3 Halaman Kriteria

Gambar diatas adalah tampilan halaman kiteria yang sudah dimasukkan, pengguna dapat melakukan pengeditan data.

\subsubsection{Halaman Alternatif}

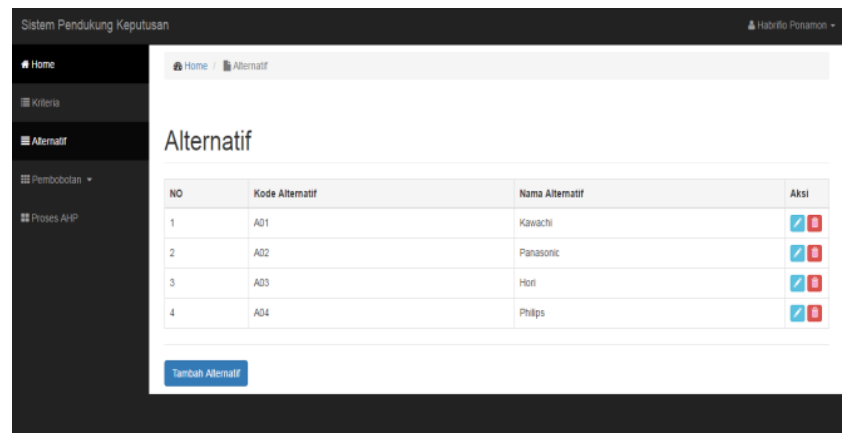

Gambar 4.4 Halaman Alternatif

Gambar diatas adalah tampilan halaman alternatif ang sudah dimasukkan, pengguna dapat melakukan pengeditan data dan menambahkan data alternatif.

\subsubsection{Halaman Pembobotan}

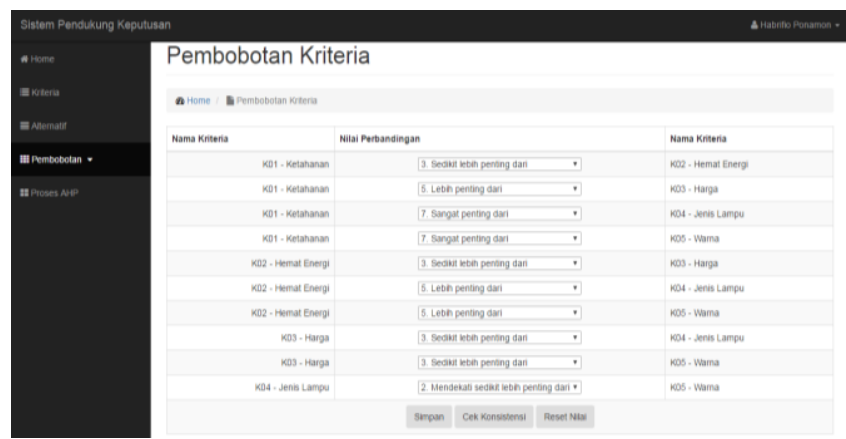

Gambar 4.5 Halaman Pembobotan Kriteria

Gambar diatas merupakan tampilan halaman pembobotan kriteria untuk menginput nilai perbandingan setiap kiteria dan juga melakukan simpan data, cek konsistensi dan reset nilai.

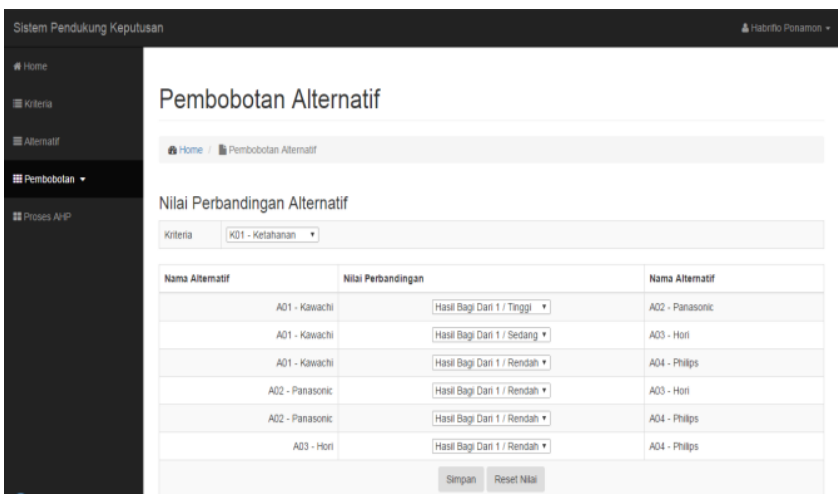

Gambar 4.6 Halaman Pembobotan Alternatif

Gambar diatas adalah tampilan halaman pembobotan alternatif dangan melakukan input data setiap alternatif . 


\subsubsection{Halaman Proses AHP}

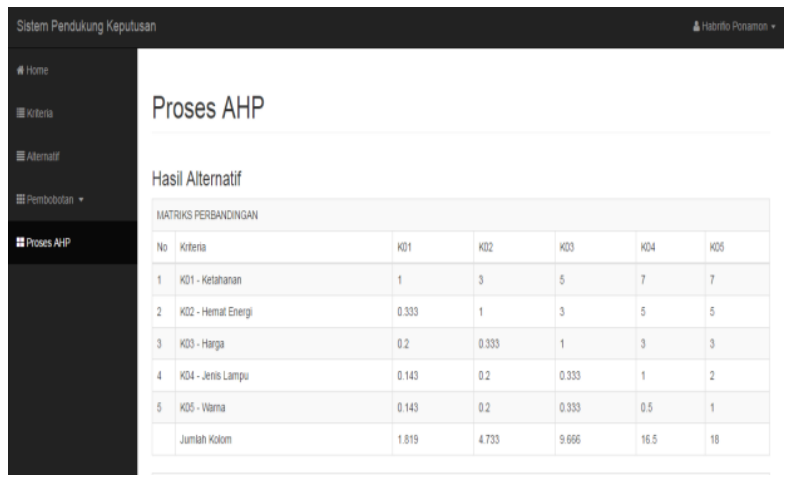

Gambar 4.8 Matriks Perbandingan Berpasangan

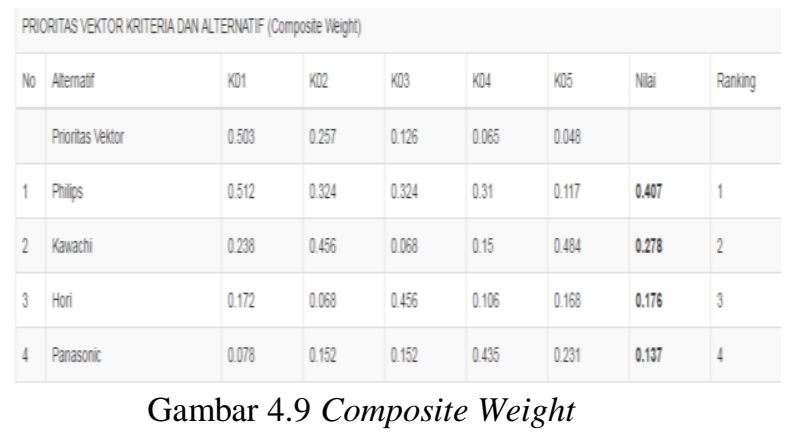

Setelah mendapatkan nilai keseluruhan prioritas dari setiap kriteria dan alternatif maka disimpulkan merek yang menjadi pilihan pertama atau rangking 1 adalah Philips.

\section{PENUTUP}

\subsection{Kesimpulan}

1. Dari hasil penelitian ini, telah dihasilkan suatu Sistem Pendukung Keputusan Pemilihan Jenis Lampu untuk Pencahayaan Ruangan dengan menggunakan metode AHP sebagai sarana untuk mengambil keputusan dalam memilih jenis atau merek lampu yang akan digunakan dalam ruangan.

2. Berdasarkan hasildari contoh perhitungan AHP dengan melakukan pembobotan terhadap kriteria dan alternatif untuk memilih jenis atau merek lampu yang digunakan maka terpilih merek lampu yang terbaik yaitu Philips.

3. Dengan adanya sistem pendukung keputusan ini dapat membantu masyarakat untuk membeli jenis lampu yang akan digunakan dengan lebih cepat dan mudah dalam menentukan pilihan.

\subsection{Saran}

Penulis menyadari bahwa sistem pendukung keputusan yang dibuat masih banyak kekurangan seperti pembobotan yang harus lebih disederhanakan dan desain interface yang lebih menarik dan penulis mengharapkan agar kedepanya nanti sistem pendukung keputusan yang akan dibuat bisa lebih dikembangkan lagi seperti menambahkan kriteria dan alternatif atau mengembangkan sistem menggunakan tools lain.

\section{DAFTAR PUSTAKA}

[1] Jaka P, Muhammad. 2014. Aplikasi Bimbingan Skripsi Online Mahasiswa Jurusan Pendidikan Matematika Fakultas Matematika dan Ilmu Pengetahuan Alam Universitas Negeri Yokyakarta. Skripsi Program S1 Pendidikan Universitas Negeri Yokyakarta.

[2] Jacobs, Albert Andri Philip. 2014. Analisa Perancangan Sistem Pendukung Keputusan Admisi Siswa Baru menggunakan Analytical Hierarchy Process di SMA Negeri 2 Manado.

http://ejournal.unsrat.ac.id/index.php/informatika/arti cle/view/4048/3564 tanggal akses 20 Mei 2016

[3] Darmasetiawan, Christian, Lestari Puspakesuma. (1991). Teknik Pencahayaan dan Tata Letak Lampu Jilid 1 Pengetahuan Dasar. PT. Gramedia Widiasarana Indonesia. Jakarta.

[4] Nuh, Muchamad. 2012. Pengembangan Sistem Informasi Presensi Siswa Pada Sekolah Menengah Atas (SMA) Negeri Rembang Berbasis Finger Print. http://ijns.org/journal/index.php/speed/article/view/1 098 tanggal akses 11 Mei 2016

[5] Lemantara, Julianto. 2013. Rancang Bangun Sistem Pendukung Keputusan Pemilihan Mahasiswa Berprestasi Menggunakan Metode AHP dan Prmothee. Fakultas Teknik Universitas Gadjah Mada Yokyakarta.

[6] Roger, S. Pressman, 2010. Rekayasa Perangkat Lunak Edisi 7, Andi. Yogyakarta

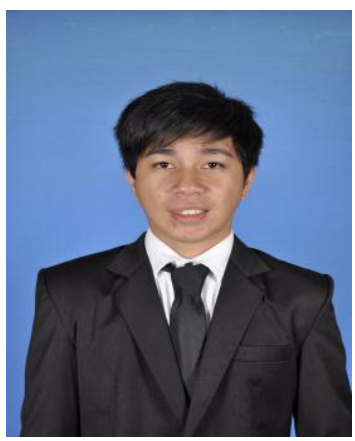

Sekilas dari penulis dengan nama lengkap Habrifio Chandradirgant Ponamon, lahir di Remboken, Minahasa, Provinsi Sulawesi Utara, anak ke 1 dari 2 bersaudara. Dengan Pendidikan Sekolah Dasar Negeri Tampusu. Kemudian melanjutkan ke Sekolah Menengah Pertama Negeri 1 Remboken. Kemudian melanjutkan ke Sekolah Menengah Atas Negeri 1 Remboken. Setelah lulus tahun 2010 melanjutkan ke Perguruan Tinggi di Universitas Sam Ratulangi Manado dengan mengambil Jurusan Teknik Informatika. Pada tanggal 13 Juni 2017 Penulis Resmi lulus di Teknik Informatika Universitas Sam Ratulangi Manado dan menyandang gelar Sarjana Komputer. 